\title{
DESCRIPTIVE STUDY ON LACRIMAL GLAND LESIONS IN A TERTIARY EYE CARE CENTRE
}

\author{
Rajendran Vijay1, Ravikumar Anand², Anbazhagan Amudha³, Srinivasan Muralikrishnan4, Jothimani Dheebalakshmi5, \\ Govindaraju Harshini ${ }^{6}$
}

\begin{abstract}
${ }^{1}$ Assistant Professor, Department of Ophthalmology, Madurai Medical College, Madurai, Tamilnadu. ${ }^{2}$ Assistant Professor, Department of Ophthalmology, Madurai Medical College, Madurai, Tamilnadu. ${ }_{3}^{3}$ Assistant Professor, Department of Ophthalmology, Madurai Medical College, Madurai, Tamilnadu. $4 J u n i o r$ Resident, Department of Ophthalmology, Madurai Medical College, Madurai, Tamilnadu. 5Junior Resident, Department of Ophthalmology, Madurai Medical College, Madurai, Tamilnadu. 6Junior Resident, Department of Ophthalmology, Madurai Medical College, Madurai, Tamilnadu.
\end{abstract}

\section{BACKGROUND}

ABSTRACT

There has been an increasing interest among ophthalmologists to study the management algorithms of lacrimal gland lesions. Unlike other ophthalmic conditions, lacrimal gland lesions have difficulty in clinical examination, diagnosis and surgical approach, as final diagnosis cannot be accurately predicted. Occurrence of these lesions can have relationship with age, gender, demographic and other socioeconomic factors.

Aims and Objectives: To study the demographic profile, clinical features, treatment options and outcome of lacrimal gland lesions; to determine demographic profile, clinical presentation, management algorithm and treatment outcomes of patients with various lacrimal gland lesions.

\section{MATERIALS AND METHODS}

A descriptive study of lacrimal gland lesions from the period of June 2012 to July 2017 are included for this study. Data included age, gender, place, ocular complaints, visual acuity, laterality, proptosis, EOM restriction and mass description. All patients underwent imaging, biopsy and histopathology. Treatment and follow-up was analysed.

\section{RESULTS}

A total of 45 patients presented to our orbit department with lacrimal gland lesions from June 2012 to July 2017, of whom 22 patients were males (48\%) and $23(52 \%)$ were females. The age of presentation ranged from 7 - 64 years. In our study, the patients were clinically classified into six categories- Benign, Malignant, Inflammatory, Infective, Lymphoproliferative and Structural lesions. Benign and malignant tumours are completely rare, below 10 years. There is significantly increased incidence of structural lesions (Dacryops) presented in this study. Rare tumours of Haemangiopericytoma, Adenocarcinoma, Langerhans cell histiocytosis and Tuberculous dacryoadenitis were reported in this case series. Treatment options include lateral orbitotomy, excision/ incisional biopsy, histopathological examination, postoperative steroids, chemotherapy and chemoradiotherapy depending on the nature of the lesion. In 6 months and 1-year follow-up, recurrence is seen only in two cases of adenoid cystic carcinoma.

\section{CONCLUSION}

In any lacrimal gland lesion imaging, lateral orbitotomy and biopsy with appropriate treatment and follow-up is mandatory in all cases.

\section{KEYWORDS}

Lacrimal Gland, Tumours, Orbitotomy, Biopsy, Histopathology.

HOW TO CITE THIS ARTICLE: Vijay R, Anand R, Amudha A, et al. Descriptive study on lacrimal gland lesions in a tertiary eye care centre. J. Evolution Med. Dent. Sci. 2018;7(17):2095-2098, DOI: 10.14260/jemds/2018/469

\section{BACKGROUND}

There has been an increasing interest among ophthalmologists to study the management algorithms of lacrimal gland lesions. Unlike other ophthalmic conditions, lacrimal gland lesions have difficulties in clinical examination, diagnosis and surgical approach, as final diagnosis cannot be

'Financial or Other Competing Interest': None.

Submission 13-03-2018, Peer Review 05-04-2018,

Acceptance 12-04-2018, Published 23-04-2018.

Corresponding Author:

Dr. Rajendran Vijay,

41-B1, Nehru Nagar, Chidambaram Road,

Jayankondam-621802, Ariyalur District,

Tamilnadu.

E-mail: vijaylaksha7@gmail.com

DOI: $10.14260 /$ jemds $/ 2018 / 469$ accurately predicted. Occurrence of these lesions can have relationship with age, gender, demographic and other socioeconomic factors.

Large variations in the types of lesions in lacrimal gland have lead to varieties in the series published by individual authors and different institutions. While Mayo et al reported the incidence of adenoid cystic carcinoma to be more common followed by benign mixed tumour, malignant mixed tumour and adenocarcinoma in his study of 83 patients between 1948 - 1997.1 Reese et al reported pleomorphic adenoma to be twice as common as adenoid cystic carcinoma in his study comprising 112 patients. $^{2}$

Now-a-days pseudotumours and lymphoproliferative disorders are being more common. It is important to differentiate between these groups, as some of these conditions are life threatening. 
Lacrimal gland lesions are experienced in various age groups. Primary tumours with rapid progression is mostly seen in children and adolescents. ${ }^{3}$ Lymphomas are predominantly seen in adult life. Primary and secondary tumours has equal occurrence in middle age. Secondaries are more common in old age. 4

The present study has been aimed to study the demographic profile, clinical features, treatment options and outcome of lacrimal gland lesions that have been reported to a tertiary care centre at Madurai from the year 2012 - 2017.

\section{Aims and Objectives}

1. To determine demographic profile of patients presenting with lacrimal gland lesions including age and gender distribution

2. To describe various clinical presentations of lacrimal gland lesions.

3. To study the management algorithms and histological features of different lacrimal gland lesions.

4. To determine the treatment outcomes in patients with various lacrimal gland lesions.

\section{MATERIALS AND METHODS}

1. Cases presenting with lacrimal gland lesions from the period of June 2012 to July 2017 were included in this study.

2. Descriptive study conducted from June 2012 to July 2017.

\section{Inclusion Criteria}

1. All patients irrespective of age who presented to our clinic with clinical/ radiological/ pathological evidence of lacrimal gland lesion.

2. Patients who consented for the study.

\section{Exclusion Criteria}

All patients not willing for undergoing the study or lost for follow-up.

\section{Analysis}

In this series, we have studied 45 cases of lacrimal gland lesions reported in our Orbit clinic from June 2012 to July 2017. The following were the observations.

\begin{tabular}{|c|c|c|c|c|}
\hline \multirow{2}{*}{$\begin{array}{l}\text { Sl. } \\
\text { No. }\end{array}$} & \multirow{2}{*}{ Lacrimal Gland Lesions } & \multirow{2}{*}{$\begin{array}{l}\text { No. of } \\
\text { Cases }\end{array}$} & \multicolumn{2}{|c|}{ Sex } \\
\hline & & & Male & \begin{tabular}{|l|} 
Female \\
\end{tabular} \\
\hline 1 & $\begin{array}{c}\text { Benign } \\
\text { Pleomorphic Adenoma }\end{array}$ & 13 & 7 & 6 \\
\hline 2 & $\begin{array}{c}\text { Malignant } \\
\text { Adenoid Cystic Carcinoma } \\
\text { Haemangiopericytoma } \\
\text { Adenocarcinoma }\end{array}$ & $\begin{array}{l}5 \\
1 \\
2\end{array}$ & $\begin{array}{l}3 \\
1 \\
-\end{array}$ & $\begin{array}{l}2 \\
- \\
2\end{array}$ \\
\hline 3. & $\begin{array}{c}\text { Inflammatory } \\
\text { Pseudo Tumour } \\
\text { Sarcoidosis } \\
\text { Non-specific Adenitis }\end{array}$ & $\begin{array}{l}5 \\
2 \\
2\end{array}$ & $\begin{array}{l}3 \\
- \\
-\end{array}$ & $\begin{array}{l}2 \\
2 \\
2\end{array}$ \\
\hline 4 & $\begin{array}{c}\text { Infective } \\
\text { TB Adenitis }\end{array}$ & 2 & 2 & - \\
\hline 5 & $\begin{array}{c}\text { Lymphoproliferative } \\
\text { Disorders } \\
\text { Non-Hodgkin's Lymphoma } \\
\text { Atypical Lymphoid } \\
\text { Hyperplasia } \\
\text { Langerhans Cell }\end{array}$ & $\begin{array}{l}3 \\
2 \\
1\end{array}$ & $\begin{array}{l}2 \\
2 \\
-\end{array}$ & $\begin{array}{l}1 \\
-\end{array}$ \\
\hline
\end{tabular}

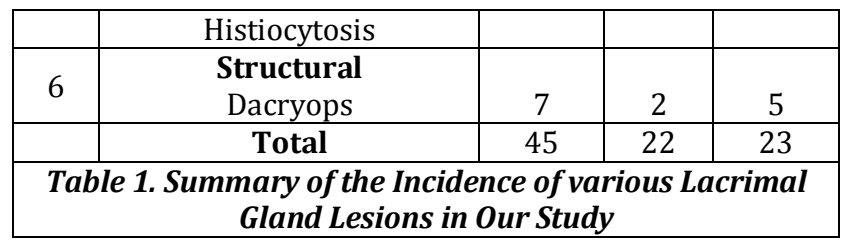

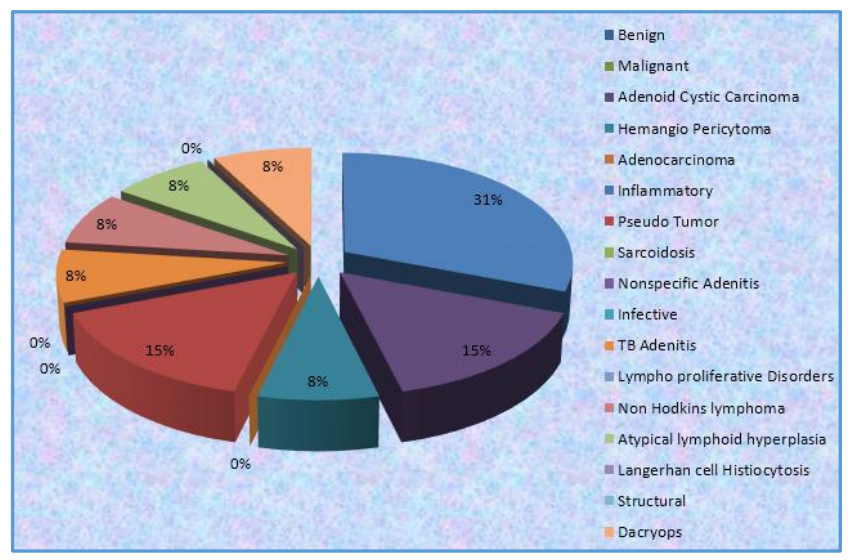

Chart 1. Percentage of various Lacrimal Gland Lesions observed in Our Study

\begin{tabular}{|c|c|c|c|c|c|c|c|c|c|}
\hline $\begin{array}{l}\text { Sl. } \\
\text { No. }\end{array}$ & Type of Tumour & $\begin{array}{c}\text { Total } \\
\text { No. } \\
\text { of } \\
\text { Case }\end{array}$ & $\begin{array}{c}0- \\
10 \\
\text { yrs. }\end{array}$ & $\begin{array}{c}10- \\
20 \\
y r s\end{array}$ & $\mid \begin{array}{c}20- \\
30 \\
y r s\end{array}$ & $\begin{array}{c}30- \\
40 \\
\text { yrs }\end{array}$ & $\mid \begin{array}{c}40- \\
50 \\
\text { yrs. }\end{array}$ & $\begin{array}{c}50- \\
60 \\
\text { yrs }\end{array}$ & $\begin{array}{l}60- \\
70 \\
\text { yrs }\end{array}$ \\
\hline 1 & $\begin{array}{l}\text { Pleomorphic } \\
\text { Adenoma }\end{array}$ & 13 & - & 2 & 4 & 3 & 2 & 2 & - \\
\hline 2 & Dacryops & 7 & - & 3 & - & 2 & 2 & - & - \\
\hline 3 & Pseudotumour & 5 & 1 & - & - & - & 2 & 2 & - \\
\hline 4 & $\begin{array}{l}\text { Non-Hodgkin's } \\
\text { Lymphoma }\end{array}$ & 3 & - & - & - & 1 & 2 & - & - \\
\hline 5 & $\begin{array}{c}\text { Adenoid Cystic } \\
\text { Carcinoma }\end{array}$ & 5 & - & - & - & - & 3 & - & 2 \\
\hline 6 & Sarcoidosis & 1 & - & - & - & - & - & - & 1 \\
\hline 7 & $\begin{array}{c}\text { Atypical Lymphoid } \\
\text { Hyperplasia }\end{array}$ & 2 & - & - & - & 2 & - & - & - \\
\hline 8 & $\begin{array}{c}\text { Langerhans Cell } \\
\text { Histiocytosis }\end{array}$ & 1 & - & 1 & - & - & - & - & - \\
\hline 9 & TB Adenitis & 2 & - & - & - & - & - & - & 2 \\
\hline 10 & Adenocarcinoma & 2 & - & - & - & - & - & - & 2 \\
\hline 11 & Haemangiopericytoma & 2 & - & - & - & - & 2 & - & - \\
\hline 12 & Non-Specific Adenitis & \begin{tabular}{|l|l|}
2 \\
\end{tabular} & $\begin{array}{ll}- \\
\end{array}$ & - & - & \begin{tabular}{l|l}
- \\
\end{tabular} & - & - & 2 \\
\hline \multicolumn{10}{|c|}{$\begin{array}{l}\text { Table 2. Age-Wise Distribution of various Lacrimal Gland } \\
\text { Lesions }\end{array}$} \\
\hline
\end{tabular}

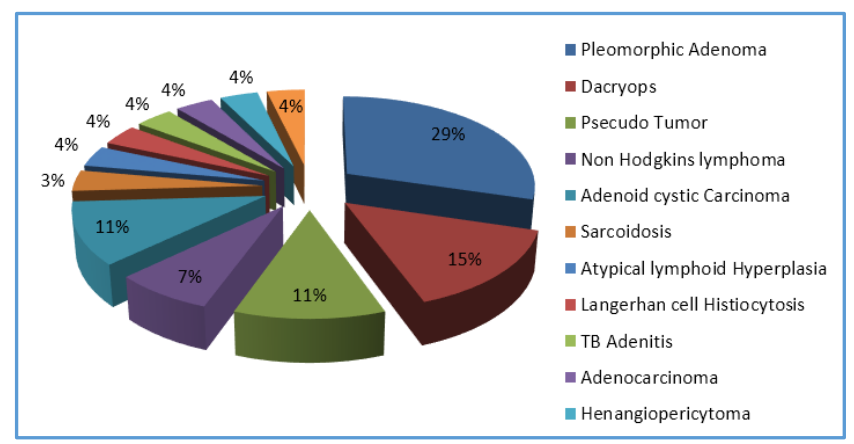

Chart 2. Distribution of various Lacrimal Grand Lesions 


\begin{tabular}{|c|c|c|c|c|c|}
\hline State & Tamilnadu & Kerala & Andhra & $\begin{array}{c}\text { West } \\
\text { Bengal }\end{array}$ & Maldives \\
\hline $\begin{array}{c}\text { No. of } \\
\text { cases }\end{array}$ & 30 & 8 & 3 & 2 & 2 \\
\hline \multicolumn{6}{|c|}{ Table 3. Demographic Profile } \\
\hline
\end{tabular}

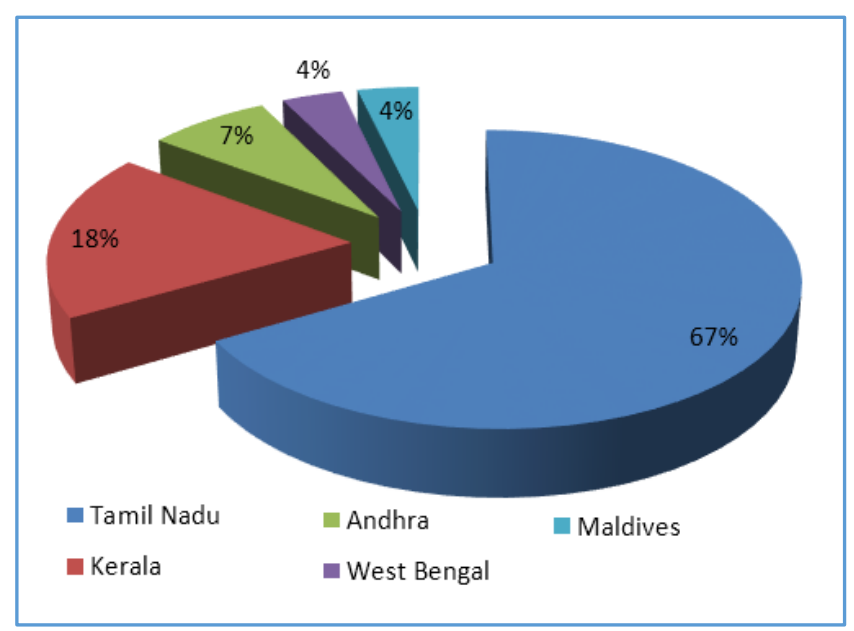

Chart 3. Demographic Profile

\begin{tabular}{|c|c|c|c|}
\hline \multicolumn{2}{|c|}{ Lateral Orbitotomy } & & \\
\hline Excision & $\begin{array}{c}\text { Incisional } \\
\text { Biopsy }\end{array}$ & $\begin{array}{c}\text { Chemo- } \\
\text { Radiotherapy } \\
\text { (Post } \\
\text { Excision) }\end{array}$ & $\begin{array}{c}\text { Chemotherapy } \\
\text { (Post } \\
\text { Excision) }\end{array}$ \\
\hline 28 & 8 & 5 & 4 \\
\hline \multicolumn{3}{|c|}{ Table 4. Treatment Given } \\
\hline
\end{tabular}

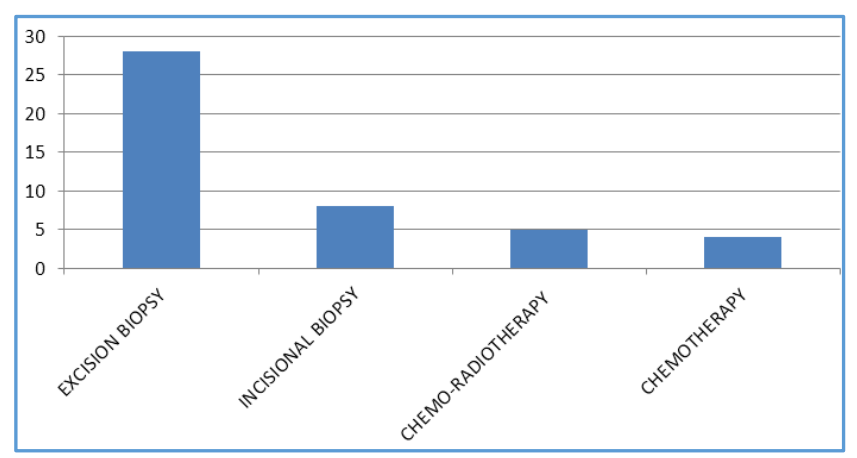

Chart 4. Treatment Given

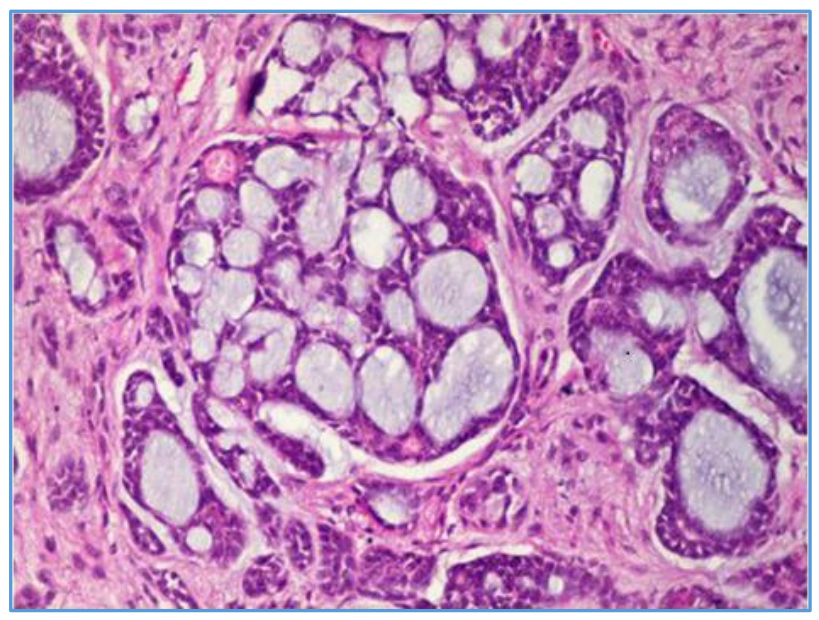

Adenoid Cystic Carcinoma of Lacrimal Gland

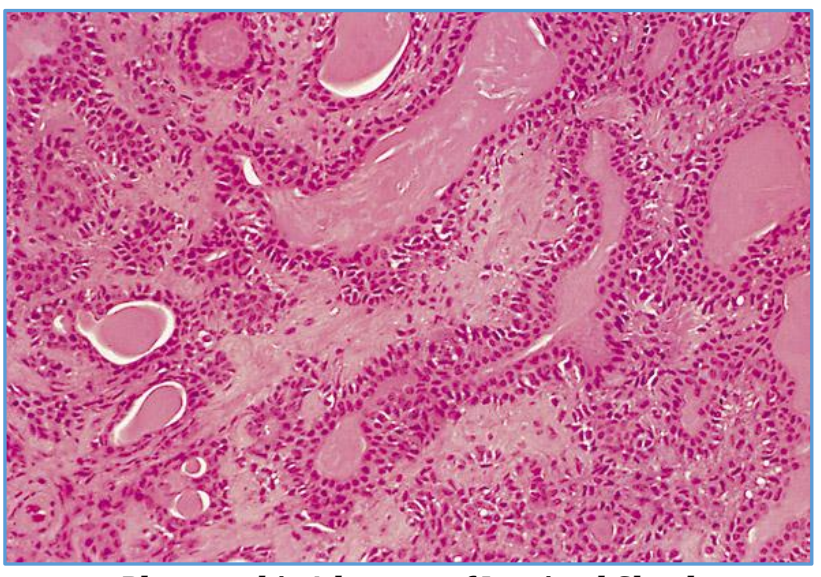

Pleomorphic Adenoma of Lacrimal Gland

\section{RESULTS}

1. A total of 45 patients presented to our orbit department with lacrimal gland lesions, of whom 22 patients were males (48\%) and $23(52 \%)$ were females. The age presentation ranged from 7 - 64 years.

2. The patients were clinically classified into six categoriesBenign, Malignant, Inflammatory, Infective, Lymphoproliferative and Structural lesions.

3. Among structural lesions 7 patients $(15.5 \%)$ presented with Dacryops. There were 5 female and 2 male patients. Patients with dacryops underwent lateral orbitotomy and mass excision in toto. All the seven patients responded well with no recurrence.

4. In dacryoadenitis diagnosed among 10 patients (22\%), 5 patients were male and 5 were female. Two cases of tuberculous adenitis involving lacrimal gland were identified. They were treated with excision biopsy followed by anti-tuberculous drugs with no recurrence.

5. In this category of dacryoadenitis, three patients presented with necrobiotic granulomatous inflammation for which they underwent excision biopsy and one was diagnosed as sarcoid and the other two were diagnosed with non-specific adenitis. All of them were treated with steroids with no recurrence.

6. Remaining 5 patients with dacryoadenitis were diagnosed as pseudotumour. They responded well with steroids.

7. Among 6 patients (13\%) presented with lymphoproliferative disorders, two patients presented with bilateral lacrimal gland enlargement. One patient was diagnosed as Langerhans cell histiocytosis, for which he underwent incisional biopsy followed by steroids with no recurrence.

8. Three patients were diagnosed as non-Hodgkin's Lymphoma (B-cell type). They underwent excision biopsy followed by chemotherapy alone. These 3 patients responded well with treatment with no recurrence. Remaining two patients with atypical lymphoid hyperplasia were treated with steroids.

9. Nine patients $(20 \%)$ in this study were diagnosed as malignant lesions, 5 had adenoid cystic carcinoma, two with adenocarcinoma and two with haemangiopericytoma.

10. Among 5 patients with adenoid cystic carcinoma, 3 were male and two were female. These patients were treated with lateral orbitotomy and excision biopsy followed by chemoradiotherapy and regular follow-up. 
11. Haemangiopericytoma (intermediate grade) was identified in two male patients. Adenocarcinoma (basaloid types) was reported in two female patients. All of them underwent mass excision biopsy through lateral orbitotomy with no recurrence during follow-up.

12. Among 13 benign tumours reported in this series, all patients presented with pleomorphic adenoma. Six patients were males and seven were females with equal sex preponderance. The age of presentation ranged from 10 - 60 years. Duration of symptoms ranged from 4 months to 6 years.

13. The commonest presentation in these patients with pleomorphic adenoma was painless, insidious onset and orbital mass. The treatment included complete excision without violating the capsule. There was no recurrence during follow-up.

\section{DISCUSSION}

In this study of lacrimal gland lesions, 45 cases have been reported. This study is comparable to Henderson Series (1994), ${ }^{4}$ Rootman Series (1999), ${ }^{5}$ Reese (1956)2 ${ }^{2}$, Ashton (1975), ${ }^{6}$ Stewart (1979), ${ }^{7}$ Shields (1989),, ${ }^{8}$ British Columbia orbit clinic series (1976 - 1999) ${ }^{9}$ and Dr. Usha Kim, Aravind Eye Hospital series (2005 - 2008). This study has its own unique features, viz. observation of rare tumours like Haemangiopericytoma, Adenocarcinoma and Langerhans cell histiocytosis were reported in this case series. Haemangiopericytoma was not included in other comparable case series like British Columbia orbital clinic series. This study has increased incidence of structural lesions (Dacryops).

Lacrimal gland lesions have wide mode of clinical presentation and Histopathological diagnosis. Lacrimal gland lesions can be conveniently divided into two groups. First group with lesions confirming to lacrimal gland (Benign lesions), which presents with painless lacrimal gland mass with insidious onset. Pleomorphic adenoma is the common benign tumour in this study. All patients need excision biopsy without violating capsule and follow-up is needed.

The second group is with lesions not confirming to clinical picture of lacrimal gland. This group contains variety of lesions like structural lesions (Dacryops), lymphoma, malignant tumours and dacryoadenitis. For Dacryops, complete excision biopsy is to be done.

Adenoid cystic carcinoma is the commonest malignant tumour arising from lacrimal gland. This tumour has high recurrence rate of 40 to 100 percent in various studies. In our study, we found recurrence of 75 percent after a follow-up for 2 years. Proper follow-up is needed in these cases to detect metastasis, especially to lung.

Lymphoproliferative disorders involving lacrimal gland presented with equal gender preponderance and bimodal presentation, which is more in third-to-fifth decade.

In cases with bilateral lacrimal gland involvement and with suspicious malignancy, immediate, complete metastatic workup with immunohistochemistry confirmation is needed to prevent recurrence and to improve life expectancy of patients.

In all non-specific dacryoadenitis cases, who did not respond to medical treatment, infective aetiology especially tuberculosis should be ruled out. Mostly, all patients with lacrimal gland lesions need lateral orbitotomy and excision biopsy.
Cases with suspected infective and non-specific inflammatory aetiology and orbital invasion (where complete excision is not possible) should be subjected to incisional biopsy.

Early and accurate diagnosis with proper follow-up and counselling is needed in all lacrimal gland lesions, so that satisfactory outcome can be expected.

\section{CONCLUSION}

In this study of lacrimal gland lesions, 45 cases were reported. Benign and malignant tumours were completely rare, below 10 years. Acute dacryoadenitis can occur at any age. Complete ophthalmic examination with appropriate investigations is needed to identify underlying aetiology, so that treatment plan can be tailored to each patient individually. Benign tumours were commonly seen in the age group of 20 - 40 years and malignant tumours were common in $60-70$ years. Most common benign tumour was pleomorphic adenoma. Since they underwent complete excision without violating capsule, no recurrence was seen in this case series. Adenoid cystic carcinoma was the commonest lacrimal gland malignant tumour with recurrence rate of $75 \%$ in 3 years follow-up in this series. There was significant proportion of structural lesions (Dacryops) presented in this study. Incisional biopsy also had an important role in this study in some cases where complete excision was not possible. Post-surgical chemoradiotherapy was beneficial in adenoid cystic carcinoma. Post-surgical chemotherapy was beneficial in non-Hodgkin's lymphoma.

\section{REFERENCES}

[1] https://www.mayoclinic.org/diseasesconditions/salivary-gland-cancer/symptomscauses/syc-20354151.

[2] Reese AB. The treatment of expanding lesions of the orbit with particular regard to those arising in the lacrimal gland. Am J Ophthalmol 1956;41(1):3-11.

[3] Coop ME. Pseudo tumor of the orbit. Br J Ophthalmol 1961;45(8):513-42.

[4] Henderson JW, Farrow GM. Orbital tumors. Philadelphia: WB Saunders Co., 1973: p. 555.

[5] Rootman J, White VA. Changes in the 7th edition of the AJCC TNM classification and recommendations for pathologic analysis of lacrimal gland tumors. Arch Pathol Lab Med 2009;133(8):1268-71.

[6] Ashton N. Epithelial tumors of the lacrimal gland. Modern problems in Opthamology 1975;14:306-23.

[7] Stewart WB, Krohel GB, Wright JE. Lacrimal gland and fossa lesions: an approach to diagnosis and management. Opthalmology 1979;86(5):886-95.

[8] Shields CL, Shields JA. Lacrimal gland tumors. Int Ophthalmol Clin 1993;33(3):181-8.

[9] Katz SE, Rootman J, Vangveeravong S, et al. Combined venous lymphatic malformations of the orbit (socalled lymphangiomas). Association with noncontiguous intracranial vascular anomalies. Ophthalmology 1998;105(1):176-84. 